\title{
Un/making the British Asian male athlete: race, legibility and the state
}

\begin{abstract}
This article explores the social construction of the British Asian male sport star. It foregrounds an analysis of the racial state, primarily its biopolitical function in (re)affirming racialised models of citizenship and contemporary hierarchies of belonging. Drawing on conceptualisations of legibility, the article argues that this relationship between race and the state is necessary to understand the processes by which such athletes are made intelligible in the popular imagination. Empirically, the article focuses on the articulations, experiences and performativity of British Asian Muslim international cricketer, Moeen Ali, during the summer of 2014. It suggests that these examples reflect the contestation and de/legitimisation of various forms of social, cultural and political attachment and embodiment within the public sphere. The article argues that the extent to which athletes such as Ali are made il/legible in sport is linked inextricably to the way in which British Asians and British Muslims are made il/legible in society. Finally, the article considers the spaces, contexts and discourses within which British Asian athletes can(not) represent themselves; and the dominant forms of being, speaking and thinking with which they must conform to meet the requirements of elite sporting citizenship.
\end{abstract}

\section{Key words}

British Asians; British Muslims; Legibility; Race; Sport; State 


\section{"Here to stay, here to play": Moeen Ali, governmentalities of nation and the contested politics of (sporting) citizenship ${ }^{1}$}

"You're playing for England, Moeen Ali, not your religion" - Michael Henderson, The Telegraph, June 2014.

"I am a Muslim, yes, but I am also very English. People don't realise how proud I am to be representing my country or being from Birmingham" - Moeen Ali, Huffington Post, September 2014.

This brief, indirect exchange between a white British journalist (of unknown religion) and a British Asian Muslim international cricketer took place during the summer of 2014. Its concision cannot obscure its resonance with a series of broader socio-political issues around national identity, religion, culture and citizenship - debates that, despite claims of a nation-state increasingly at ease with its diversity, refuse to wither in the sporting arena as much as elsewhere.

This article uses Moeen Ali's articulations and experiences, and the performative statements made about him, to consider the contestation and de/legitimisation of various forms of social, cultural and political attachment and embodiment - ideological, material, stylistic, verbal - within the public sphere (Rootham et al 2015). Specifically, it addresses the ways that racialised corporeality is linked to discourses of national identity, citizenship, belonging and integration (Nagel and Staeheli 2008), together with the ways that the racial state attempts to narrow, or deny, social heterogeneities (Goldberg 2002). These themes underpin the substantive argument developed in the article: that an analysis of the relationship between race and the state is necessary to understand the processes by which the British Asian male athlete is made legible in the popular imagination.

Beginning this article with the strained dialogue between Henderson and Ali may appear trite, yet the tension between the two positions is palpable. One standpoint perceives the relationship 
between religion, ethnicity and national identity to be conflicting, unresolved and impossible even (at least in the embodied guise of normative sporting practices). It articulates a sense of 'governmental belonging', that is 'the power to have a legitimate view concerning the positioning of others in the nation... who should "feel at home" in the nation and how' (Hage 1998: 46). The opposite stance is no less assertive, but sees hyphenation and hybridity as unextraordinary, intersectional and convivial (Gilroy 2004). In contrast to the journalist's affirmation of governmentality, Ali's response is indicative of a "forced telling of the self" (Archer 2009: 74), that is the ceaseless requirement to explain and justify one's identities and affiliations. More broadly, the exchange speaks to the racialised classification of different bodies, cultures and the discourses attached to them, even when race is not made explicit. It demonstrates the manner in which these categories are produced both through the agency of the individuals involved, and the regulatory structures of the racial state (Goldberg 2002) and the sporting arena (Carter 2011). The dialogue is, then, inexorably one of unequal power relations, with Henderson's individual proclamations operating as an 'institutional speech act' (Ahmed 2012) on behalf of the state.

Michael Henderson's statement derived from his displeasure with comments that Moeen Ali made during the 2014 Test series between the England and India men's XIs. Ali - Birmingham-born and raised, a Muslim, and of Pakistani (Mirpuri) heritage ${ }^{2}$ - had stated that his distinctive long beard was a "uniform" or "label" that provided a symbolic identification with, and demonstration of, his Islamic faith. Participation on the cricket pitch, Ali maintained, was as much a matter of performing Islam as his Englishness. Reflections of this kind are common increasingly in contemporary elite sport, whether that be from British Muslims (Burdsey 2010) or players from other faiths, such as evangelical Christians (Krattenmaker 2010). Ali's thoughtful and erudite 
statements were rejected nonetheless by Henderson, who perceived religious - or, at least, "nonChristian" - affiliation to be inappropriate and divisive in the sporting arena. The journalist's refusal to accept and endorse Ali's intersectional identity - and, in essence, his misreading and misrepresentation of it - needs to be understood in the context of the increasing prominence of religion in debates around multiculturalism (Modood 2005). This is manifest primarily via claims promulgated (erroneously) over the last decade by politicians and other popular constituencies regarding a perceived reluctance by Muslim communities to identify with Britishness. ${ }^{3}$ It is also indicative of a nuanced but oppressive mode of contemporary state biopolitics that has emerged in response: one that seeks to circumscribe forms of allegiance, agency and mobility, while creating a binary of those Muslims that qualify or "count" as British citizens, and those that do not (Bhattacharyya 2006, Kapoor 2013a).

At face value, Henderson's original comments were initiated by concerns about religious identity. One perhaps ought then to avoid an instinctive inclination to situate them within conventional analyses of ethnic and racial discrimination in sport. However, a more intricate and contextual reading of these (and other) remarks suggests that discourses around race, ethnicity and religion actually cohere and overlap in popular representations of the player. Ali may regard his ethnic, racial and religious identities as distinct categories, or he may view them as composite. This article suggests that these classifications are separated rarely in the popular imagination. A critical evaluation of everyday performances of self and institutional workings demonstrates that they are intertwined (Bhattacharyya 2006). Put simply, racialisation does not work through the category of race alone; rather, it interacts and intersects with gender and class (Meer 2013). 
This is highlighted in many demotic responses to Ali's selection for the England squad. The announcement, earlier in 2014, of his inclusion led to a spate of racist comments on Facebook. Epithets such as "Osama bin Laden" and "Borat"4 were posted, along with comments about "foreigners playing for England" and a reference to "Birmistan" - seemingly a nod to Birmingham's sizeable British Pakistani communities and the city's construction in the contemporary popular imagination as a site of Islamic radicalisation (Hodgson 2014). It is important, however, to recognise 'the ambiguous ways in which multicultural intimacies and visceral hatred coexist' (Nayak 2010: 2389), together with the nuanced and complex ways that different publics respond to sport stars. Evidence points to Ali's great popularity as well. His name is chanted by fans at matches, media portrayals are often amiable - albeit employing discourses that centralise stereotypical attributes, and drawing trivial comparisons to other players - and he won the award of Professional Sportsman of the Year for the city of Birmingham in $2014 .^{5}$

We have been here before. But had we not moved on? It seems fairly incongruous that a minority ethnic person playing for England should cause comment, let alone consternation, given the advance of (sporting) multicultural Britain. Yet this encapsulates the paradoxical nature of modern sport; fundamental both to the eradication and reproduction of racial inequalities and stereotypes, as well as a supposedly commonsense space in which to (re)inscribe the racial parameters of national belonging. The exchange between Ali and Henderson tells us something about the contemporary politics of multiculture, racial vernacular and the role of the state as well, in that we are dealing here with a coded discourse. It may speak of religion, but it draws intermittently on ideas of race, ethnicity and culture. Moreover, this episode speaks to broader conflations of nation and state $-\mathrm{a}$ form of slippage that elides the power of the latter in the processes under scrutiny 
(Carter 2011). While Ali's international sporting participation is fundamentally a question of nation (he plays for England), the way it is framed in relation to his ethnic, racial and religious identities brings the role of the state firmly into the equation (he is a British citizen).

Racism, John Solomos and Les Back (1996: 213) remind us, is 'a scavenger ideology'. It 'draws selectively upon the past, present and imagined future, distilling complex fears and anxieties' (Meer and Nayak 2013: 13). Similarly, Claire Alexander (2014: 1785) notes the 'continued and unresolved' nature of racism, and its capacity to 'build on - and recycle - former images and discourses'. Cricket is more than a mere backdrop here. An 'Indian game accidentally discovered by the English' (Nandy 2000: 1), cricket's (post-)colonial pitfalls and possibilities have been articulated notably over the last half century (e.g. James 1963, Marqusee 1998, Nandy 2000) and remain germane to the present analysis. Historically, English cricket's relationship with India and Pakistan, and, over the last half century, British Asian communities, has been characterised often by acrimony and racial exclusion. The Othering of British Asian players has centred recurrently on accusations - infamously from Conservative MP Tebbit and Wisden Cricket Monthly author Robert Henderson ${ }^{6}$ in the 1990s - of divided national loyalties and the "threat" posed by their cultural inassimilability with the embodied cultures of English cricket (Williams 2001). English cricket's role as a sporting symbol of hegemonic whiteness and racialised articulations of national identity has been challenged in the twenty-first century, with the long-list of players capped by the country players now including a distinct corpus of names: Afzaal, Ali (plural), Bopara, Habib, Hussain, Khan, Mahmood, Mascarenhas, Panesar, Patel, Rashid, Shah, Shahzad and Solanki. There has also been a marked shift in the balance of power within international cricket administration towards Asian nations. This is demonstrated by the International Cricket Council's 
(ICC) relocation from London to Dubai and the growing significance of limited-overs competitions, such as the Indian Premier League (IPL), in relation to Test matches (Rumford 2007). These global power geometries offer an important context for the debates addressed in this article.

Although drawing essentially on a single case study, this article exposes themes and connections beyond the micro-politics of one individual's experiences and a single form of physical culture. As Joshua Newman and Michael Giardina (2014: 419) contend, 'as the body moves - as it performs, sweats, runs and jumps - it is thrust into a complex web of scientific discourses, biomedical rationalities, spatial arrangements, geopolitical networks, corporate imperatives, and intersubjective identity politics' (see also Gilchrist et al 2015). It is therefore necessary to look outside sport to a wider exploration of the state's biopolitical role in creating, regulating, monitoring and securing racialised bodies; and to address the links between the local, national and global, at the level of discourse, structure and ideology, in an understanding of British Asian identities (Alexander 2008).

These connections were no more evident than in the third match of the England-India Test series in July 2014. This game took place at the same time that the Israeli government was undertaking an aerial bombardment of the Gaza Strip. Moeen Ali took to the field wearing two plastic wristbands, embossed with the phrases "Save Gaza" and "Free Palestine". 7 While the England and Wales Cricket Board (ECB) defended the act, the ICC stated that 'equipment and clothing regulations do not permit the display of messages that relate to political, religious or racial activities or causes during an international match' (cited in Wilson 2014a). The ICC proscribed 
any subsequent use of the wristbands. ${ }^{8}$ This position denied the already politicised nature of this particular white public space (Hill 2008), as well as the extant political and racialised elements of sporting structures, institutions, and normative sporting cultures in general.

Ali stated that his gesture was humanitarian and not political. It was not out of line with much contemporaneous public opinion in the UK. ${ }^{9}$ Yet, according to Telegraph columnist, Dan Hodges, Ali's choice was a 'very bad' one and 'needlessly divisive'; it was believed to promote Muslim exceptionalism and to reinforce negative stereotypes of young British Muslim men (Hodges 2014). This inference that Ali was somehow culpable for any individuals who used his actions to buttress their own prejudices is problematic. Not only does it place a weighty burden of (over)representation on a player who may or may not want this responsibility (Farred 2003), but it also inhibits his agency. It promotes a performative essentialism that refuses to see Ali (or allow him to exist) outside dominant discursive constructions of British Muslim men, and it reinforces ethno-religious governmentalities of what such individuals are expected or allowed to do or say. Simultaneously it permits the silence of white communities, itself also a political act.

At the end of summer 2014, Ali espoused a more "acceptable" position, urging against any British Muslims considering travelling to Iraq and Syria to fight for a radical Islamist organisation, known (among other designations) as ISIS (Islamic State of Iraq and Syria). Unlike the organic gesture of the wristbands, Ali's statement was a direct response to a journalist's question (Hasan 2014). This is an important distinction. These forms of questioning and reporting are indicative of the performative nature of dominant discourses about Ali, which limit the parameters and possibilities of his legibility (see below). Following Judith Butler (1993a: 2), performativity is understood here 
'not as a singular or deliberate "act", but, rather, as the reiterative and citational practice by which discourse produces the effects that it names'. It is recognised, as Sara Ahmed (2012) has shown, that discourse can be 'non-performative' too, when the speech act does not produce what it names. This is not necessarily due to the absence of appropriate conditions or intent; it is in essence the act's function. The speech act can be interpreted as performative though - as enacting what it names - and accordingly acts as a signifier of its assumed effect.

\section{Notes on standpoint and the cultural politics of representation}

This article attempts to forge analytical connections between discursive constructions of the British Asian, particularly Muslim (see below), male athlete and the role of the state. It explores the biopolitical function of the racial state in (re)affirming racialised models of citizenship and contemporary hierarchies of belonging (Back et al 2012), and discusses how they are "played out", literally, in this form of popular culture. In this sense, citizenship is understood as 'a field of biopolitical techniques and practices (legal, social, moral) through which populations are controlled and fashioned' (Tyler 2010: 62).

Very few British Asian male athletes have achieved success and stardom within national and global sportscapes. All have received in-depth sociological analysis: boxing brothers Amir Khan (Burdsey 2007) and Haroon Khan (Barron 2013), and cricketer Monty Panesar (Burdsey 2013). The absence of British Asian women from elite sport in the UK is even more pronounced, accentuated by the broader marginalisation of female sport in the mainstream, particularly in the realm of media and political discourses. As a result we still know very little about the experiences of British Asian women and girls in high level sport. Critical insights are emerging within the 
academy that shed light on British Asian, mainly Muslim, amateur sportswomen (e.g. Ahmad 2011, Ratna 2011, Samie 2013) and Muslim sportswomen in an international capacity (Samie and Sehlikoglu 2015). Yet the visibility and audibility of these sportswomen beyond the academic realm can be limited. They are excluded from popular debates about sporting nationhood and permitted rarely positions of influence within dominant Western sporting institutions. More broadly, the particular gendered and sexualised manner in which British Asian (and other minority ethnic) women have been subjected to state racism must be acknowledged, as do the notable ways that women have engaged in activism against the state, and its public and private structures and institutions (e.g. Wilson 2006). This was highlighted in 2015 by the dehumanising conditions experienced by migrant women at the Yarlswood detention centre in Bedfordshire, England, and the protests against their treatment. An appreciation of these gender dynamics requires this article to make its focus on male sport explicit, including recognition of the problematic aspects of maintaining a masculinist scholarly tradition.

This article emphasises the ways that race operates as a source of classification, subordination and exclusion within sport, plus its centrality to state practices around citizenship, belonging and mobility. In a reflective essay on the foundational text, The Empire Strikes Back (Centre for Contemporary Cultural Studies 1982), Claire Alexander (2014: 1787) states that if the challenge for the CCCS Collective was to get race and racism on the agenda at all, the challenge today is to get racism back on the agenda'. She makes the critical point that within political discourse - and, we should add, within some academic thought - the significance and naming of race, and recognition of its structural manifestations, have been obfuscated by a focus on identity, culture, nation, migration and super-diversity (see also Fortier 2008, Harries 2014, Meer and Nayak 2013). 
This is not to underplay the purchase of such concepts; it is a matter of ensuring that their connections to notions of race and racialisation remain intact. As Nasar Meer (2013: 504) points out, 'instead of trying to neatly delineate social tendencies that are intertwined, they should instead be understood as a composite of cultural racism’.

In introducing the notion of intersectionality, Kimberlé Crenshaw (1989) refers to the multidimensional lived experiences of marginalised individuals (see also Collins 2008). Scholars such as Nira Yuval-Davis (2011: 8) have called for a broader focus, arguing that 'the boundaries of intersectional analysis should encompass all members of society and thus intersectionality should be seen as the right theoretical framework for analysing social stratification' (see Birrell and McDonald 2000 on sport; see May 2015 for a contemporary overview). With specific reference to Muslim communities, Alexander (2013: 6) articulates that:

Race equality and religious equality agendas have become increasingly separate, and academic research in these areas has also become distinct. We could make the same argument about migration studies, and the danger is the same - that it is now seemingly possible to talk about religion without race and race without reference to religion. In the first instance we risk separating out Muslims from a broader struggle for equality, and in the second we run the risk of subsuming or erasing the differences between experiences, priorities, groups and subjectivities for a one-size-fits-all definition of racism.

In trying to tease out some of the intricacies of this intersectional position, elements of the current discussion refer to British Asian men in general, while in some parts a focus on Muslims specifically is more germane. At other times, the connections between Asianness and Muslimness are delineated more closely. This conceptual elasticity is not unproblematic. A multi-dimensional approach can run the risk of reinforcing inadvertently essentialist constructions within dominant discourses that conflate the ethnic and religious categories under consideration. To be clear, this article views the various identity categories and modes of being under focus as overlapping and 
interconnecting; yet it recognises the tensions between (and within) them, and rejects any suggestion that they are coterminous.

Lastly, the potential hazards of inadvertent academic complicity with the dominant political discourse and the process of Othering (Spivak 1988) warrant reflection. This article critiques dominant forms of discourse, representation and processes of legibility, but in turn discusses British Asian athletes within particular frames of reference, in conjunction with Western theoretical traditions and through the authorship of white, male academic privilege. As Peggy Phelan (1993) articulates, making marginalised individuals and groups visible is always a matter of power: what or who is being represented; and by, and to, whom. The objective here is to write about dominant discourses as a means of trying to write against them. This essay engages with these hegemonic modes of representation in order to trouble and subvert them.

\section{The racial state}

Before exploring how Moeen Ali's eminence connects to notions of legibility, the role of the state and its co-constitution with structures of race require consideration. ${ }^{10}$ This is not to deny that racial politics emerge from, and exist, beyond the state. For instance, they materialise within communities themselves and in forms of popular culture. Individuals and groups construct and define their identities as well, and they can resist those imposed from above (Omi and Winant 2015). Nonetheless, this article maintains that foregrounding the role of the state is important in understanding the discursive construction of racialised athletes. 
David Theo Goldberg (2002: 8) suggests that the state can be defined as 'a more or less coherent and discrete entity in two related ways: as state projects underpinned and rationalized by a selfrepresented history as state memory; and as state $\operatorname{power}(s)$. More specifically, he argues that:

The racial state is racial not merely or reductively because of the racial composition of its personnel or the racial implications of its policies - though clearly both play a part. States are racial more deeply because of the structural position they occupy in producing and reproducing, constituting and effecting racially shaped spaces and places, groups and events, life worlds and possibilities, accesses and restrictions, inclusions and exclusions, conceptions and modes of representation. They are racial, in short, in virtue of their modes of population definition, determination, and structuration. And they are racist to the extent such definition, determination and structuration operate to exclude or privilege in or on racial terms, and in so far as they circulate in and reproduce a world whose meanings and effects are racist (ibid.: 104).

While he would reject a reductionist categorisation that his intellectual oeuvre on racial phenomena is purely Foucauldian (Goldberg 2014), Goldberg's (2002) foregrounding of race within biopolitics represents a foundational understanding of the modern state. ${ }^{11}$ As Michael Omi and Howard Winant (2015: 138) point out, 'emphasizing the political dimensions of race and racism allows us to discern the contours of the racial system, to understand what racial hegemony looks like, to specify its contradictions, and to envisage alternative scenarios' (see also Lentin and Lentin 2006). Critically, this requires recognition not only that racial states exist in a plurality (Goldberg 2002), but also that their internal power struggles can be as significant as their external challenges. Moreover, contemporary state racisms often exceed national boundaries to the extent that it may be more accurate to refer to 'a globally integrated machinery of state racisms' (Bhattacharyya 2006: 139).

The relationship between the politics of race and various state practices in twenty-first century Britain is highlighted by Ben Pitcher (2009), primarily how the state constructs and reinforces the boundaries of nationhood, both in a literal and legislative sense. He remarks that, 'by shaping the 
trajectory of dominant understandings of those marked out as racially different, the state plays its part in identifying, inculcating and reproducing that difference' (ibid.: 29-30). Accordingly, through the politics of diversity management, (im)migration, and security, the state is 'engaged in definition, regulation, governance, management, and mediation of racial matters they at once help to fashion and facilitate' (Goldberg 2002: 109-10). These processes translate to the categorisation, control and securitisation of different marginalised communities (as well as their homogenisation and often their conflation) which operate as processes of state racism (Tyler 2010, Kapoor 2015). As Omi and Winant (2015: 145) articulate in their noteworthy text on the state's role in creating and applying signification through the process of racial formation:

The phrase "body politic", of course, refers not only to the collective body, the "nation" or its equivalents; it also refers to the politicized body. Here we are arguing that the phenomic dimensions of race are among the central components of this phenomenon. Race and racism not only politicize the social but render up the human body into the burning heart of the state as material for the social control. State racial policy is directed against the racial body, in such forms as surveillance, profiling, policing, and confinement.

While hierarchies of oppression are to be avoided, and the experiences of other racialised communities warrant their own attention and action, much of the British state's regulatory governance focuses currently on British Muslim communities (Kundnani 2014). This is especially the case with young men, who are 'used for retaining/sustaining embedded racial hierarchies, essentially enabling a biopolitics which in turn could be remobilised for the state's own ends' (Kapoor 2013b: 223). Consequently they become 'the figure upon which the state can practice new techniques of repression and control' (ibid.: 227).

\section{Representation, legibility and British Asian male sporting male bodies}

The opening vignette about Moeen Ali encourages an exploration of various ways that British Asian male bodies become "legible" within, and through, the realm of elite sport. Legibility is 
employed here to describe the manner in which bodies are recognisable, intelligible, unambiguous and legitimate in relation to normative and performative scripts and speech acts. Visibility, on the hand, implies more prosaically 'the state of being able to be seen' (Fleetwood 2010: 16). These concepts are understood as a relational process rather than static conditions (Goldberg 1997), and as having ontological and political affects and connotations as well as literal ones. It is the contention here that bodies might be visible (seen) without being rendered legible (understood); but also that processes of legibility and illegibility can create various forms (e.g. social, political) of hyper-visibility or invisibility. To this end, the following questions underpin the discussion: What is the relationship between visibility, legibility and the British Asian athlete? What role does the state play in influencing their reception within the realm of sport? What, or how, can the British Asian athlete speak, and what are the repercussions of these speech acts? In exploring these questions, the components and effects of power, race and racialisation are foregrounded here. As Judith Butler (1993b) remarks, 'the visual field is not neutral to the question of race; it is itself a racial formation, an episteme, hegemonic and forceful'.

The relationship between legibility and the state is theorised, perhaps most famously, by James Scott (1998), who argues that making their citizens legible is a key concern for modern states. According to Michel-Rolph Trouillet (2001: 126), this involves a 'legibility effect', that is 'the production of both a language and a knowledge for governance and of theoretical and empirical tools that classify and regulate collectivities'. In terms of popular culture, Mark Anthony Neal's (2013) analysis of portrayals of black male bodies in the United States provides a valuable starting point. Through case studies of a range of diverse African-American men, Neal argues that:

That the most "legible" black male body is often thought to be a criminal body and/or a body in need of policing and containment - incarceration - is just a reminder that the black male 
body that so seduced America is just as often the bogeyman that keeps America awake at night. Thus "legible" black male bodies, ironically, bring welcome relief, a comforting knowingness (ibid: 5).

Neal's work offers a number of valuable observations about male racial embodiment that are germane to the current discussion, beyond simply illuminating which types of racialised bodies become legible. He highlights the dichotomous ways that legible and illegible masculinities are constructed, and discusses the complexities, nuances and ambiguities that characterise what are regarded as less legible forms of being. Neal also talks about the repercussions of dominant representations of il/legibility, in terms of the psychosocial reassurance they offer through the confirmation of existing racial schema. Moreover, Neal addresses the politics of trying to disrupt these hegemonic constructions and the possibilities that arise from such interventions: 'the radical potential of rendering "legible" black male bodies - those bodies that are all too real to us illegible, while simultaneously rendering so-called illegible black male bodies legible - those black male bodies we can't believe are real - legible' (ibid.: 8). This can create a particular type of racialised affect that troubles and subverts the dominant Western vision in certain spheres and practices (Fleetwood 2010).

Despite the book's athletic cover - an image taken from Hank Willis Thomas' Strange Fruit collection - the book does not address sport at all. ${ }^{12}$ This is a curious omission, especially given recent debates within the US about the relationship between seemingly "illegible" black males and sport, such as "out" gay men, Jason Collins and Michael Sam. ${ }^{13}$ Or, perhaps this absence actually tells us something about the relationship between racial identity, legibility and sport itself, in that illegible bodies are marginalised, disguised or excluded. In short, they are denied the opportunity to be visible, let alone legible, in this form of popular culture. 
The social construction of the black athlete has been examined elsewhere, primarily the manner in which he (as it usually is) is "made" and becomes legible within the popular imagination (Fleetwood 2015). Amy Bass (2002: 3), for instance, describes the black athlete as 'one of the most visible integrated racial subjects in modern society' (emphasis in original). She highlights the ubiquity of the black athlete in the mass media, its integration within sporting cultures and a degree of (sometimes superficial) acceptance among, and celebration by, white fans. Yet, as Ben Carrington (2010: 2) points out, the meanings attached to the black athlete have been struggled over and contested continuously, resulting in a range of substantive shifts: 'submissive and threatening, often obedient, occasionally rebellious, revolting and in revolt, political and compromised, a commodity and commodified'. These constructions are rarely discrete. Dichotomous imagery and descriptions operate frequently at the same time and in the same place, irrespective of their apparent contradictions. In construction and representation, the black athlete thus becomes 'typically exceptional'; emblematic of an essentialised category of blackness, but also beyond human in terms of stereotypical physical capacities (ibid.). Critically, Carrington points out that the construction of the black athlete is not actually about blackness itself; but emerged from a 'white masculinist fear of loss and impotence, revealing the commingling of sex, class, race and power' (ibid.: 3 ).

How might we begin, then, to understand, conceptually, the notion of the British Asian athlete, or the South Asian athlete more broadly as Sameer Pandya (2013) asks? Central to this task, as Gayatri Chakravorty Spivak (1988) suggests, is an appreciation of the mechanics of the constitution of the Other in this popular cultural sphere. At one level, the broader processes of racial formation that pertain to the black athlete are in operation here as well. The particular 
commingling of power relations around race, gender and masculinity that has rendered the black athlete "knowable" has inhibited the visibility of, and circumscribed the legibility afforded to, the British Asian athlete as well (Kim 2014). Yet, within this set of power relations, the British Asian athlete is subjected to a distinctly different form of racialised corporeal and cultural construction, and thus requires a distinct analytical frame. The British Asian athlete is largely "invisible" - or, at the very least, inaudible - in sporting, media and popular discourse: s/he is depoliticized; s/he is seen as effete, passive or timid; s/he is not - cannot - be a commodity in the sense of being recognised and valued in the global marketplace. In short, elite sport has been regarded rarely as a space in which the bifurcated process of making British Asian males il/legible can occur (Kalra 2009). Their bodies are regarded habitually as anomalies in this space, on account of physical and cultural attributes. The British Asian elite athlete, it seems, has been almost an ontological impossibility.

Occasionally British Asian athletes have achieved sporting success and stardom. The various discursive tropes through which they have been decipherable thus require consideration: narratives of exceptionalism; the subjective reproduction of biological stereotypes (such as the notion, embedded in the British colonial project, that British Asians make "natural" cricketers due to their perceived strong hand-eye co-ordination); and (sub)cultural processes within sport that erase certain racial signifiers from their bodies and practices (Burdsey 2010). These latter procedures entail partial interpretations of their identities, focusing on those forms of subjectivity and affiliation that (are seen to) reflect existing racial schema and dovetail with the putative post-racial nature of sport. This legibility is ideological as well, in terms of its relations to athletes' compatibility with, and (perceived) endorsement of, certain political doctrines. For instance, Amir 
Khan exhibits a "Westernised" stylistic demeanour, forms of conspicuous consumption and a legible British Asian desi identity (see Bakrania 2013, Kim 2012). Then there is his performance of a bounded British Asian Muslim masculinity and his deference to white authority figures, such as coaches. Politically, he has also been perceived to embody and endorse hegemonic discourses around multiculturalism, community cohesion and the 'war on terror' (Burdsey 2007). Conversely, Monty Panesar embodies a "soft" (sporting) masculinity which reinforces popular stereotypes about South Asian male physicality, passivity and effeminacy. He certainly looks "Asian enough" but, on account of his Punjabi Sikh heritage - regarded historically as a loyal "martial race" - does not threaten the established racial and religious status quo, physically, politically or ideologically (Burdsey 2013). Haroon Khan - Amir's less famous younger brother - made the decision to represent Pakistan at the 2010 Commonwealth Games in Delhi, having previously boxed for England. Explanatory discourses within the media represented this first as a "threat", thus situating it within broader Islamophobic rhetoric. Khan's choice was portrayed later as an act of last resort, having been overlooked by the England selectors, rather than a reflection of cultural hybridity and fluid diasporic citizenship (Barron 2013).

Structures, typologies and classifications initiated by the state are adopted (and occasionally modified) by sport - as a mixture of private and public institutions - which then determine individuals' capacities to become in/visible, in/audible and il/legible in this realm. The structures of the state and those of other social institutions, such as elite sport, do not therefore exist in a binary; rather, they are entwined and co-productive (Das 2004). Michael Omi and Howard Winant (2015: 124) note that "race is a "crossroads" where social structure and cultural representation meet', while David Theo Goldberg (2002: 109) refers to the racial state as 'a political force 
fashioning and fashioned by economic, legal, and cultural forces' (emphasis in original). The connections between structure and signification - 'racial projects' (Omi and Winant 2015) - in sport are addressed by Ben Carrington (2010). He develops the notion of 'sporting racial projects' as a means of illuminating the ways that 'sports become productive, and not merely receptive of racial discourse' (ibid: 66). In the context of South Asian participation, Stanley Thangaraj (2012, 2013) demonstrates how men's amateur basketball leagues represents a principal sphere in which ideas about race derived from the state are imposed onto sport. They are taken up and embodied, but also, importantly, resisted, in order to (re)signify symbolic orders of race (and gender and sexuality), and to interrogate racialised notions of citizenship in the US. With basketball again the reference point, Sumaya Samie (2013) shows how the British Pakistani Muslim female body is also reduced to classifications and discourses derived originally from the state. Samie argues that “"who" sporting Muslims females are, both "beneath" and/or outside a discursive identity of the veil, and what their relationship is like with their body, remains a mystery and a topic of much contention' (ibid.: 257).

Although focusing on transnational migration, Thomas Carter's (2011) forges instructive connections between sport and state practices. He argues that sporting migrants' mobility and capacity to travel unhindered, as global sporting citizens, is determined by their visibility (at point of departure and point of arrival). This visibility, as a manifestation of sovereign power, is underpinned by the extent to which their identity (broadly as a member of a particular ethnonational community) is understood and validated by the public, and is legible both to state and sporting authorities. These processes facilitate certain migrants (but not others) to become 'legitimate in relation to bureaucratic power and discipline' and therefore removed from 'the space 
of illegality' (ibid. 176) that renders them immobile and unwelcome. As mechanisms by which the apparatuses of governmentality operate, visibility and legibility are not simply about race and ethnicity; they are gendered and heteronormative too (Farred 2003, Goldberg 2002).

Moeen Ali is not, of course, a migrant, but similar processes can be identified. His visibility in the sporting arena can only be understood in the context of the racial state; namely, the ways that the state seeks to draw particular lines of ethno-religious closure and to make certain racialised bodies "known", and thus subject to regulation and control. The state ensures simultaneously that the identities that underpin them are, paradoxically, inaudible and fundamentally "unknowable", through restrictive forms of (mis)representation and (dis)enfranchisement. ${ }^{14}$ At the current time, the young British Muslim male becomes legible through particular constructions, discourses and speech acts: ones that demonise and criminalise him, and often mark him as an illegitimate citizen; that vindicate state domestic and foreign policy; and that uphold the racial status quo. These tropes are performative in that they create a restrictive interpretative frame that draws repeatedly on and refuses to locate such individuals outside - issues such as radicalisation in cities such as Birmingham, and British militants joining ISIS. The pervasiveness of this framing enables it to percolate into otherwise cordial depictions. A newspaper article by the journalist, Yasmin AlibhaiBrown (2014), is a case in point. While recognising the wider meaning of the term, describing Ali as an 'exemplary jihadi' does little to liberate the player from dominant constructions. Moreover, her reference to 'sporting a Taliban beard' may play on popular stereotypes, but it reflects ultimately the pejorative conflation of religion, culture and ideology, particularly imagined ideas of the Islamic terrorist. This dominant discourse of legibility is employed elsewhere through the 
"nickname" used by fans and as a marketing ploy by his club, Worcestershire: "The Beard That's Feared". ${ }^{15}$

The case study of Moeen Ali encourages us to think about visibility and legibility as complex, equivocal and relational; and as operating differently across temporal and spatial contexts. It also allows us to consider a number of relationships, such as those between race and the state, sport and the state, and legibility and citizenship. The current analysis shows how Muslim masculinities need to be understood in the context of normative ones, in that they are subject to forms of power and governmentality that influence their construction and articulation (Kalra 2009). Following David Theo Goldberg (2014: 93), 'the notion of "governmentality" becomes productive because it has broader applicability, not tied simply or reductively to institutional apparatuses'. For a sportsperson like Ali, the extent to which he is il/legible in sport is linked inseparably to the way in which British Asians and British Muslims are made il/legible in society. More specifically, the processes of state regulation and signification - as well as media representation and sporting ascription - that make him visible and legible in society are those that mark him as Other in the related, but distinct, realm of sport. In other words, the way he is made "knowable" in the broader context - corporeal markers and affiliations - are precisely those attributes that sport rejects habitually as "out of place", such as articulating a political stance and refusing to underplay one's ethno-religious alterity.

\section{("What" or "how") can the British Asian athlete "speak"? Transruptions, vernaculars, activism}

In a spin on Gayatri Chakravorty Spivak's (1988) foundational question - Can the subaltern speak?

- the concluding section of this article asks: Can the British Asian male athlete speak? And, if he 
can: Where, when and how is this sanctioned? Following Spivak, this section considers the parameters within which the British Asian athlete can articulate their experiences: the spaces, contexts and discourses within which they can(not) represent themselves; and the dominant forms of being, speaking and thinking with which they must conform to meet the requirements of elite sporting citizenship.

Esther Rootham and colleagues (2015: 1529) encourage us to think about how 'the modalities through which [minority ethnic young men] narrate and practice their individual spatial sense of belonging reflect wider policy and political discourses which position them as differently regarded citizens'. The performances and articulations of Moeen Ali might offer an emerging, individualised 'transruption' (Hesse 2000) to dominant, racialised discourses of nation and the embodied practices, politics and poetics of elite British sport. As Barnor Hesse (2000: 17) states, a multicultural transruption 'comprises any series of contestatory cultural and theoretical interventions which, in their impact as cultural differences, unsettle social norms and threaten to dismantle hegemonic concepts and practices' (emphasis in original). For Ali, transruption occurs through the personal-as-political: manifest in visual markers; articulate public proclamations on identity, religion and politics; and an organic, vernacular anti-racism with deep roots in British Asian communities (Ramamurthy 2013). Embodying a racialised masculinity that is varyingly hyper-visible and invisible (Fleetwood 2010, Nagel and Staeheli 2008), Ali's own performativity demonstrates "the ways in which less "hegemonic" masculine identities are managed at the everyday and local level in public space through practices of resistance and subversion' (Barber 2015: 441). 
The previous section suggested that, understood through a particular lens, these might be bounded and transient acts though. The effects of dominant modes of representation, the absence of critical mass of similar players, his own (inadvertent) reproduction of dominant narratives, and the regulations of elite sport regarding what one can do or articulate in the public sphere can all be prohibitive. Indeed, there are certain sporting structures and cultures that remain ostensibly beyond transruption. For example, one might consider the scenes at The Oval, London in August as England clinched the Test Series against India. As his team-mates sprayed bottles of champagne, Ali could be seen running for cover behind the sponsor's podium to avoid any contact with the alcohol - a stark reminder of the embodied, racialised sporting practices that marginalise and Other those who do not endorse the dominant (sub)cultural code (see Burdsey 2010).

Or maybe this is too simplistic an interpretation of the process, which limits our understanding of Ali's relationship with his sport, the complexity of his identity and his latent oppositional role. $\mathrm{He}$ is not constituted and constrained purely by discourse or embodied sporting practice, and his own agency is important. As Judith Butler states in an interview with Vikki Bell:

The real task is to figure out how a subject who is constituted in and by discourse then recites that very same discourse but perhaps to another purpose. For me that's always been the question of how to find agency, the moment of that recitation or that replay of discourse that is the condition of one's own emergence (Bell 1999: 165).

Perhaps we need to consider other meanings and manifestations of transruption; as more fluid, complex, ambiguous and subtle than we may have appreciated previously, but as equally significant and subversive? In this regard, analyses of two other minority ethnic male sport stars are instructive: Fijian-American professional golfer, Vijay Singh, and the black French exfootballer, Lilian Thuram. According to Sameer Pandya (2013: 220), Singh represents 'a particular type of early twenty-first-century minority sports figure whose racial and political consciousness 
is neither consistently articulated nor inherently submerged'. Pandya does not locate Singh's silence towards the media - his rejection of role model status, not discussing his migratory background and personal life, and not endorsing the discourse of post-racialism in the US - as case of being enigmatic. Instead, following Martin Manalansan (2010), it is understood as a matter of disaffection - towards traditional forms of masculinity, expectations to foreground his ethnicity and requests to politicise sport. Singh is, then, 'a new type of sports figure who is not political in the way that we understand the term, and yet politics are certainly not absent' (ibid: 229).

The theme of alternative politics is likewise taken up by Grant Farred (2012). He discusses issues of representation and citizenship in the context of the public statements made by Thuram about, and on behalf of, disenfranchised and excluded black, Berber and Arab communities in urban France. Illuminating the intricate and problematic connections between representation and absence, Farred argues that 'there can be no representation without absence of the Other' and, as such, representation 'represses voice as much as it insists all subjects are politically audible' (ibid.: 1054). He concludes that '[Thuram's] silence, especially should it come after so much - such public speaking, could be more salient and disruptive than his continued rhetorical interventions' (ibid.: 1055). As demonstrated more recently with African-American sportsman Marshawn Lynch $\left(\right.$ Crunk Feminist Collective 2015) ${ }^{16}$, these forms of silence - often symbolic rather than literal are inexorably political, comprising a refusal to be "known" only within hegemonic tropes.

Throughout the summer of 2014, a slight semantic shift could be observed, from Moeen Ali wearing Gaza wristbands and discussing his Islamic faith to denouncing ISIS and a reticence to talk about discrimination. This modification makes him a more legible and "legitimate" sporting 
body, and arguably, in time, perhaps a less "visible" one. This does not necessarily dilute Ali's political potential, for he offers a particular sense of transruption and a noteworthy vernacular mode of being. According to Farred (2003: 5), vernacular intellectuals are:

Producers, articulators and disseminators of cultural knowledge; they are public figures who contribute and create new forms of knowledge; they think carefully about what they say (as much as any conventional intellectual), how they say it, why they are moved to say it; and they understand how their rhetorical interventions connect to their original constituency.

The vernacular intellectual exists outside formal political structures and 'craft[s] a unique public space from which to speak as they address the issues of the day that directly affect their community' (ibid: 22).

By engaging with the questions of journalists in media interviews, Ali certainly responds to, and within, the dominant discourse. Indeed, these depictions necessitate the very imperative to respond to this script in the first place (Archer 2009). Maybe he perceives there to be benefits from speaking within such conventional channels as well, in terms of the opportunities to explain his faith and intersectional identities, and to provide more constructive and corrective responses to derogatory depictions of his communities. Ali, it seems, is comfortable in this sphere: combining erudition, civility and humility in his statements; knowing what and when to speak; and - while he does not talk of being representative of them - understanding how his articulations relate to the communities from which he has emerged. Perhaps he does not feel constrained by the dominant discourse though, and is able to oppose, challenge, influence or reconfigure it from a subaltern standpoint. As Patricia Noxolo (2009: 61) asks, 'what if the voiceless choose to speak in a voice that is other to what we "give" them?'. We know less about the player away from the game and the media spotlight, but there may be different modes of being and complementary discourses with which Ali is equally at ease. These exist outside the dominant frame, yet are no less important in 
engaging with political and humanitarian concerns, seeking social justice and empowering marginalised communities. They can be highly effective and influential despite their sometimes understated delivery.

Ali provides a(nother) compelling case for exploring the relationship between sport, politics, activism and the sporting hero, primarily the use of sport as a platform from which to "speak" in the public sphere. His position is not unique, as has been shown in relation to a number of athletes and sports over the last fifty years (e.g. Carrington 2010, Farred 2003, James 1963, Marqusee 2005). It is, however, distinctive, in the context both of British Asian and Muslim communities and contemporary British sport. In making this claim, one must be cognisant of the fact that it is a particular subaltern representation that is being selected for celebratory intellectual claim in this article (Ahmed 2000). Moreover, this essay does not offer the player or his contemporaries any greater "voice" than many of the sources under critique (Spivak 1998). Nonetheless, Ali's articulations, performances and experiences elsewhere encourage us to think differently about British Asian and Muslim participation in sport; and they provide potentially a discursive frame for talking about, and engaging in, sporting resistance and activism, in ways that are not couched in traditional intersections of race, gender and class. In Moeen Ali, we are witnessing, possibly, a more important and influential British Asian Muslim sporting hero than we have witnessed thus far. 


\section{Acknowledgements}

I am very grateful to the guest editors of this special themed section for their insight, support and encouragement with this article; and to the two anonymous SRO reviewers, whose comments improved this article immeasurably. I am indebted to Thomas Carter and Stan Thangaraj for their constructive comments on earlier drafts. I thank Thomas, along with Paul Gilchrist, for pushing me continuously to think differently about the minority ethnic sports hero, and to Mark Erickson for encouraging me to develop ideas about discourse and agency.

\section{Notes}

${ }^{1}$ The phrase in the prefix of this section title provides an alternative take on Alexander and Kim's (2014: 359) 'Here to stay, here to dance' description of twenty-first century British Asian youth cultures - itself a reference to the 1970s anti-racist slogan 'Here to stay, here to fight'.

${ }^{2}$ One of Ali's grandmothers is white British.

${ }^{3}$ Statistics show that, in England, British Asian groups are actually far more likely that white British ones to describe themselves as exclusively British. Muslims are four times more likely to identify in this way than Christians (Centre on Dynamics of Ethnicity 2013).

${ }^{4}$ Borat is a 2006 comedy movie, based around the adventures of the eponymous fictional Kazakhstani journalist.

${ }^{5}$ Ali was booed by some British Indian supporters when he played for England in a Twenty20 match at Edgbaston, in his home city of Birmingham, in September 2014. Angus Porter, the Chief Executive of the Professional Cricketers' Association, argued that Ali should 'take it as a positive - you'd rather be booed than ignored' (cited in Wilson 2014b). A number of commentators were similarly quick to highlight perceived prejudice by the supporters (see, for example, Smith 2014). These claims might be read as an attempt to shift accusations of racism onto minority ethnic bodies, rather than (just) white ones (see Song 2014 for a critique of an emerging 'culture of racial equivalence').

${ }^{6}$ No relation.

${ }^{7}$ Malaysian cyclist, Azizulhasni Awang, competed at the 2014 Commonwealth Games with 'Save Gaza' printed on his gloves (Simpson 2014). At around the same time, a football match between the Israeli club, Maccabi Haifa, and their French opponents, Lille, was abandoned late in the game. This was due to a pitch invasion by individuals holding Palestinian flags, who also traded blows with Maccabi players (Guardian 2014).

8 The shirts worn by the England players advertised the charity Help for Heroes, while the match commemorated the one hundredth anniversary of the commencement of World War One. This reflects the increasing role of British sport events, clubs and competitions in the 'hero'-fication of militarism (Kelly 2013). 
${ }^{9}$ Ali was supported publicly by other cricketers, such as Kabir Ali (his cousin) and Azhar Mahmood. He was labelled a "silly boy" and "naïve" by his England team-mate, Steve Harmison (Hoult 2014).

${ }^{10}$ See Lentin and Lentin (2006) for a brief history of scholarship exploring the race-state relationship.

${ }^{11}$ Perhaps most famously, Robert Young (1995: 57) has written about what he regards as Michel Foucault's 'virtual silence' on race and colonialism. Others, such as Ann Laura Stoler (1995), have sought to make Foucault's application to race more overt. These linkages have been recognised primarily since the English translation of Foucault's (2003) Society Must be Defended, where the relationship between race, power and biopolitics is more pronounced (Macey 2009).

${ }^{12}$ The cover depicts an athletic black male in Nike basketball shorts and trainers, but wearing no jersey. He is facing away from the camera, with his head bowed. He is suspended from a rope noose, which hooks over the basketball held in his right arm above his head. The basketball is imprinted with NBA (National Basketball Association).

${ }^{13}$ See, for example, Anderson and McCormack (2014) on sport; and Ferguson (2004) and McGlotten and Davis (2012) for a more general discussion on the intersections between race and sexuality.

${ }^{14}$ Das (2004) suggests that this also enables the state to protect the illegibility - the 'unreadability of its rules and regulations' (ibid.: 234) - of its own constitution.

15 'Fear the Beard' is a phrase also associated with Brian Wilson, a white, Christian, American baseball player. Fans have been known to chant and display the appellation at matches, commemorative t-shirts have been produced, and Facebook and Twitter accounts exist in the beard's "honour". See Burdsey (2013) for a discussion of British Asian cricketer, Monty Panesar, and the adoption of replica beards by England cricket fans.

${ }^{16}$ At a press conference before American Football's 2015 Super Bowl, Lynch refused to engage with any questions. Referencing professional sports people's media obligations, he responded repeatedly with 'I'm here so I won't get fined' (Crunk Feminist Collective 2015). I am grateful to Sanaa Qureshi for sharing details of this case. 


\section{References}

AHMAD, A (2011) British Muslim female experiences in football: Islam, identity and the hijab, in Burdsey, D (Ed.) Race, Ethnicity and Football: Persisting Debates and Emergent Issues, Abingdon: Routledge.

AHMED, S (2000) 'Who knows? Knowing strangers and strangerness', Australian Feminist Studies, Vol. 15, No. 31, p. 49-68.

---- (2012) On Being Included: Racism and Diversity in Institutional Life, Durham, NC: Duke University Press.

ALEXANDER, C (2008) 'The problem of South Asian popular culture: a view from the UK', South Asian Popular Culture, Vol. 6, No. 1, p. 1-12.

---- (2013) The Muslim question(s): reflections from a race and ethnic studies perspective, in Alexander, C, Redclift, V and Hussain, A (Eds.) The New Muslims, London: Runnymede Trust.

---- (2014) 'The Empire Strikes Back: 30 years on', Ethnic and Racial Studies, Vol. 37, No. 10, p. 1784-92.

ALEXANDER, C and Kim, H (2014) Dis/locating diaspora: South Asian youth cultures in Britain, in Chatterji, J and Washbrook, D (Eds.) Routledge Handbook of the South Asian Diaspora, Abingdon: Routledge.

ALIBHAI-BROWN, Y (2014) 'Torture? Spying? The freedoms Britain prides itself on are illusory. We live in a secret state', Independent on Sunday. http://www.independent.co.uk/voices/comment/torture-spying-the-freedoms-britain-pridesitself-on-are-illusory-we-live-in-a-secret-state-9645163.html. Accessed 16 September 2014.

ANDERSON, E and McCormack, M (2014) 'Being a black gay male athlete', Gender and Society blog. http://gendersociety.wordpress.com/2014/05/01/being-a-black-gay-male-athlete/. Accessed 16 September 2014.

ARCHER, L (2009) Race, "face" and masculinity: the identities and local geographies of Muslim boys, in Hopkins, $\mathrm{P}$ and Gale, R (eds.) Muslims in Britain: Race, Place and Identities, Edinburgh: Edinburgh University Press.

BACK, L and SINHA, S with BRYAN, C (2012) 'New hierarchies of belonging', European Journal of Cultural Studies, Vol. 15, No. 2, p. 155-66.

BAKRANIA, F (2013) Bhangra and Asian Underground: South Asian Music and the Politics of Belonging, Durham, NC: Duke University Press.

BARBER, T (2015) 'Performing "Oriental” masculinities: embodied identities among Vietnamese men in London', Gender, Place and Culture: a Journal of Feminist Geography, Vol. 22, No. 3, p. 440-55.

BARRON, D (2013) 'Diasporic pugilists and fighting for national belonging: Haroon Khan and the 2010 Commonwealth Games', South Asian Popular Culture, Vol. 11, No. 3, p. 313-24.

BASS, A (2002) Not the Triumph but the Struggle: The 1968 Olympics and the Making of the Black Athlete, Minneapolis: University of Minnesota Press. 
BELL, V (1999) 'On speech, race and melancholia: an interview with Judith Butler', Theory, Culture and Society, 16, 2: 163-74.

BHATTACHARYYA, G (2006) Wars on our doorstep: Islamicising "race" and militarising everyday life, in Lentin, A and Lentin, R (Eds.) Race and State, Newcastle-upon-Tyne: Cambridge Scholars Publishing.

BIRRELL, S and McDonald, M (Eds.) (2000) Reading Sport: Critical Essays on Power and Representation, Boston: Northeastern University Press.

BURDSEY, D (2007) 'Role with the punches: the construction and representation of Amir Khan as a role model for multiethnic Britain', Sociological Review, Vol. 55, No. 3, p. 611-31.

---- (2010) 'British Muslim experiences in English first-class cricket', International Review for the Sociology of Sport, Vol. 45, No. 3, p. 315-34.

---- (2013) Monty Panesar and the new (sporting) Asian Britishness, in Andrews, D. and Carrington, B. (Eds.) A Companion to Sport, Oxford: Wiley Blackwell.

BUTLER, J (1993a) Bodies That Matter: On the Discursive Limits of "Sex", London: Routledge.

---- (1993b) Endangered/endangering: schematic racism and white paranoia, in GoodingWilliams, R (ed.) Reading Rodney King/Reading Urban Uprising, London: Routledge.

CARRINGTON, B (2010) Race, Sport and Politics: the Sporting Black Diaspora, London: Sage.

CARTER, T (2011) In Foreign Fields: The Politics and Experiences of Transnational Sport Migration, London: Pluto Press.

CENTRE FOR CONTEMPORARY CULTURAL STUDIES (1982) The Empire Strikes Back: Race and Racism in 70s Britain, London: Hutchinson.

CENTRE ON DYNAMICS OF ETHNICITY (2013) 'Who feels British? The relationship between ethnicity, religion and national identity in England', Manchester: University of Manchester/Joseph Rowntree Foundation.

COLLINS, P H (2008) Black Feminist Thought: Knowledge, Consciousness, and the Politics of Empowerment, Abingdon: Routledge.

CRENSHAW, K (1989) 'Demarginalizing the intersection of race and sex: a Black Feminist critique of antidiscrimination doctrine, feminist politics and antiracist politics', University of Chicago Legal Forum, Vol. 140: 139-67.

CRUNK FEMINIST COLLECTIVE (2015) 'What Marshawn Lynch and Richard Sherman teach us about respectability and black masculinity'. http://www.crunkfeministcollective.com/2015/02/03/what-marshawn-lynch-and-richardsherman-teach-us-about-respectability-black-masculinity/. Accessed 22 June 2015.

DAS, V (2004) The signature of the state: the paradox of illegibility, in Das, V and Poole, D (eds.) Anthropology in the Margins of the State, Santa Fe, NM: School of American Research Press.

FARRED, G (2003) What's My Name? Black Vernacular Intellectuals, Minneapolis: University of Minnesota Press. 
---- (2012) “"Keeping silent”: the problem of citizenship for Lilian Thuram', Ethnic and Racial Studies, Vol. 35, No. 6, p. 1040-58.

FERGUSON, R (2004) Aberrations in Black: Toward a Queer of Colour Critique, Minneapolis: University of Minnesota Press.

FLEETWOOD, N (2010) Troubling Vision: Performance, Visuality, and Blackness, Chicago: University of Chicago Press.

ADD REF

FORTIER, A-M (2008) Multicultural Horizons: Diversity and the Limits of the Civil Nation, Abingdon: Routledge.

FOUCAULT, M (2003) 'Society Must be Defended': Lectures at the Collège de France 1975-76 (trans. David Macey), London: Allen Lane.

GILCHRIST, P, Holden R and Millward, P (2015) 'Special section introduction: the political sociologies of sport', Sociological Research Online, http://www.socresonline.org.uk/20/2/15.html.

GILROY, P (2004) After Empire: Melancholia or Convivial Culture?, London: Routledge.

GOLDBERG, D T (1997) Racial Subjects: Writing on Race in America, London: Routledge.

---- (2002) The Racial State, Oxford: Blackwell.

---- (2014) Sites of Race: Conversations with Susan Searls Giroux, Cambridge: Polity Press.

GUARDIAN (2014) 'Maccabi Haifa v Lille abandoned after pro-Palestinian protesters storm pitch'. http://www.theguardian.com/football/2014/jul/24/maccabi-haifa-lille-abandonedpalestinian-protesters. Accessed 10 September 2014.

HAGE, G (1998) White Nation: Fantasies of White Supremacy in a Multicultural Society, Annandale: Pluto Press.

HARRIES, B (2014) 'We need to talk about race', Sociology, Vol. 48, No. 6, p. 1107-22.

HASAN, M (2014) 'Moeen Ali interview: "I am a Muslim, yes, but I am also very English', Huffington Post. http://www.huffingtonpost.co.uk/2014/09/11/moeenali_n_5803422.html?1410524969. Accessed 12 September 2014.

HENDERSON, M (2014) 'You're playing for England, Moeen Ali, not your religion', Telegraph. http://www.telegraph.co.uk/news/religion/10897999/Youre-playing-for-England-MoeenAli-not-your-religion.html. Accessed 12 August 2014.

HESSE, B (2000) Introduction: un/settled multiculturalisms, in Hesse, B (Ed.) Un/Settled Multiculturalisms: Diasporas, Entanglements, Transruptions, London: Zed Books.

HILL, J (2008) The Everyday Language of White Racism, Oxford: Wiley-Blackwell.

HODGES, D (2014) 'No one has gained from Moeen Ali's wristbands', Telegraph. http://blogs.telegraph.co.uk/news/danhodges/100281736/no-one-has-gained-from-moeenalis-wristbands/. Accessed 13 August 2013.

HODGSON, A (2014) 'England call up for Moeen Ali sparks racist slurs and nationality debate on Facebook', London Evening Standard. http://www.standard.co.uk/sport/cricket/england- 
call-up-for-moeen-ali-sparks-racist-slurs-and-nationality-debate-on-facebook-

9112277.html. Accessed 13 August 2014.

HOULT, N (2014) 'Azhar Mahmood threatens copycat Moeen Ali "Save Gaza” wristband protest in Surrey Twenty20 tie', Telegraph. http://www.telegraph.co.uk/sport/cricket/international/england/10999061/AzharMahmood-threatens-copycat-Moeen-Ali-Save-Gaza-wristband-protest-in-SurreyTwenty20-tie.html. Accessed 13 August 2014.

JAMES, C L R (1963) Beyond a Boundary, London: Hutchison.

KALRA, V (2009) 'Between emasculation and hypermasculinity: theorizing British South Asian masculinities', South Asian Popular Culture, Vol. 7, No. 2, p. 113-25.

KAPOOR, N (2013a) Along the fault lines of "British justice for British citizens": locating the non-/British Muslim, in Alexander, $\mathrm{C}$ et al (Eds.) op cit.

---- (2013b) Afterword: racial futures, in Kapoor N, Kalra, V S and Rhodes, J. (Eds.) The State of Race, Basingstoke: Palgrave.

---- (2015) 'Removing the right to have rights', Studies in Ethnicity and Nationalism, Vol. 15, No. 1, p. 105-10.

KELLY, J (2013) 'Popular culture, sport and the "hero"-fication of British militarism', Sociology, Vol. 47, No. 4, p. 722-38.

KIM, C (2014) 'The smell of communities to come: Jeremy Lin and post-racial desire', Journal of Intercultural Studies, Vol. 35, No. 3, p. 310-27.

KIM, H (2012) 'A “desi” diaspora? The production of "desiness" and London's Asian urban music scene', Identities: Global Studies in Culture and Power, Vol. 19, No. 5, p. 557-75.

KRATTENMAKER, T (2010) Onward Christian Athletes: Turning Ballparks into Pulpits and Players into Preachers, Lanham, MA: Rowman and Littlefield.

KUNDNANI, A (2014) The Muslims are Coming! Islamophobia, Extremism and the Domestic War on Terror, London: Verso.

LENTIN, A and Lentin, R (2006) Speaking of racism, in Lentin, A and Lentin, R (Eds.) op cit.

MACEY, D (2009) 'Rethinking biopolitics, race and power in the wake of Foucault', Theory, Culture and Society, Vol. 26, No. 6, p. 186-205.

MANALANSAN, M. (2010) Servicing the world: flexible Filipinos and the unsecured life, in Staiger, J, Cvetkovitch, A and Reynolds, A (Eds.) Political Emotions, Abingdon: Routledge.

MARQUSEE, M. (1998) Anyone but England: Cricket, Race and Class, London: Two Heads Publishing.

---- (2005) Redemption Song: Muhammad Ali and the Spirit of the Sixties, London: Verso.

MAY, V (2015) Pursuing Intersectionality: Unsettling Dominant Imaginaries, Abingdon: Routledge.

McGLOTTEN, S and Davis, D-A (Eds.) (2012) Black Genders and Sexualities, Basingstoke: Palgrave. 
MEER, N (2013) 'Semantics, scales and solidarities in the study of antisemitism and Islamophobia', Ethnic and Racial Studies, Vol. 36, No. 3, p. 500-15.

MEER, N and Nayak, A (2013) 'Race ends where? Race, racism and contemporary sociology', Sociology, DOI: 10.1177/0038038513501943.

MODOOD, T (2005) Multicultural Politics: Racism, Ethnicity and Muslims in Britain, Edinburgh: Edinburgh University Press.

NAGEL, C and Staeheli, L (2008) Integration and the politics of visibility and invisibility in Britain: the case of British Arab activists, in Dwyer, C and Bressey, C (Eds.) New Geographies of Race and Racism, Aldershot: Ashgate.

NANDY, A (2001) The Tao of Cricket: On Games of Destiny and the Destiny of Games (Second Edition), Oxford: Oxford University Press.

NAYAK, A (2010) 'Race, affect and emotion: young people, racism and graffiti in the postcolonial English suburbs’, Environment and Planning A, Vol. 42, No. 10, p. 2370-92.

NEAL, M A (2013) Looking for Leroy: Illegible Black Masculinities, New York: New York University Press.

NEWMAN, J and Giardina, M (2014) 'Moving biopolitics', Cultural Studies $\leftrightarrow$ Critical Methodologies, Vol. 14, No. 5, p. 419-24.

NOXOLO, P (2009) "My paper, my paper": reflections on the embodied production of postcolonial geographical responsibility in academic writing', Geoforum, Vol. 40, No. 1, p. $55-65$.

OMI, M and Winant, H (2015) Racial Formation in the United States (Third Edition), Abingdon: Routledge.

PANDYA, S (2013) 'Situating Vijay Singh in (Asian) America', South Asian Popular Culture, Vol. 11, No. 3, p. 219-30.

PHELAN, P (1993) Unmarked: the Politics of Performance, London: Routledge.

PITCHER, B (2009) The Politics of Multiculturalism: Race and Racism in Contemporary Britain, Basingstoke: Palgrave.

RAMAMURTHY, A (2013) Black Star: Britain's Asian Youth Movements, London: Pluto Press.

RATNA, A (2011) Flying the flag for England? National identities and British Asian female footballers, in Burdsey, D (Ed.) op cit.

ROOTHAM, E, Hardgrove, A and McDowell, L (2015) 'Constructing racialised masculinities in/through affective orientations to a multicultural town', Urban Studies, Vol. 52, No.8, p.1523-39.

RUMFORD, C (2007) 'More than a game: globalization and the post-Westernization of world cricket', Global Networks, Vol. 7, No. 2, p.202-14.

SAMIE, S F (2013) 'Hetero-sexy self/body work and basketball: the invisible sporting women of British Pakistani Muslim heritage', South Asian Popular Culture, Vol. 11, No. 3, p. 257-70.

SAMIE, S F and Sehlikoglu, S (2015) 'Strange, incompetent and out-of-place', Feminist Media Studies, Vol. 15, No. 3, p. 363-81. 
SCOTT, J (1998) Seeing Like a State: How Certain Schemes to Improve the Human Condition Have Failed, New Haven, CT: Yale University Press.

SIMPSON, W (2014) 'Malaysian cyclist could face disciplinary action after "Save Gaza" gloves protest, Independent. http://www.independent.co.uk/sport/commonwealthgames/malaysian-cyclist-could-face-disciplinary-action-after-save-gaza-gloves-protest9627907.html . Accessed 10 September 2014.

SMITH, E (2014) 'Bigotry is bigotry - shame on those who booed Moeen Ali at Edgbaston', New Statesman. http://www.newstatesman.com/lifestyle/2014/09/bigotry-bigotry-shame-thosewho-booed-moeen-ali-edgbaston. Accessed 15 October 2014.

SOLOMOS, J and Back, L (1996) Racism and Society, London: Routledge.

SONG, M (2014) 'Challenging a culture of racial equivalence', British Journal of Sociology, Vol. 65 , No. 1, p. 107-29.

SPIVAK, G C (1988) Can the subaltern speak?, in Nelson, C and Grossberg, L (Eds.) Marxism and the Interpretation of Culture, Urbana, IL: University of Illinois Press.

STOLER, A L (1995) Race and the Education of Desire: Foucault's History of Sexuality and the Colonial Order of Things, Durham, NC: Duke University Press.

THANGARAJ, S (2012) 'Playing through differences: black-white racial logic and interrogating South Asian American identity', Ethnic and Racial Studies, Vol. 35, No. 6, p. 988-1006.

---- (2013) 'Competing masculinities: South Asian American identity formation in Asian American basketball leagues', South Asian Popular Culture, Vol. 11, No. 3, p. 243-56.

TROUILLET, M-R (2001) 'The anthropology of the state in the age of globalization: close encounters of the deceptive kind', Current Anthropology, Vol. 42, No. 1, p. 125-38.

TYLER, I (2010) 'Designed to fail: a biopolitics of British citizenship', Citizenship Studies, Vol. 14, No. 1, p. 61-74.

WILLIAMS, J (2001) Cricket and Race, Oxford: Berg.

WILSON, Amrit (2006) Dreams, Questions, Struggles: South Asian Women in Britain, London: Pluto Press.

WILSON, Andy (2014a) 'Moeen Ali banned by ICC from wearing wristbands while playing for England', Guardian. http://www.theguardian.com/sport/2014/jul/29/moeen-ali-wristbandsengland-india-icc. Accessed 12 August 2014.

---- (2014b) 'PCA's attempt to defuse Moeen Ali booing row backfires', Guardian. http://www.theguardian.com/sport/2014/sep/09/pca-moeen-ali-boos-angus-porter-englandindia. Accessed 11 August 2014.

YOUNG, R (1995) 'Foucault on race and colonialism', New Formations, Vol. 25, p. 57-65.

YUVAL-DAVIS, N (2011) The Politics of Belonging: Intersectional Contestations, London: SAGE. 